\title{
Are flightless Galapaganus weevils older than the Galápagos Islands they inhabit?
}

\author{
ANDREA S. SEQUEIRA广ं, ANALÍA A. LANTERI\$, M. AMALIA SCATAGLINI§, \\ VIVIANA A. CONFALONIERI§ \& BRIAN D. FARRELL ${ }^{*}$ \\ $\uparrow$ Museum of Comparative Zoology, Harvard University, Cambridge, MA 02138, U.S.A., $₫$ Departamento Cientifico de \\ Entomología, Museo de La Plata, Paseo del Bosque s/n, (1900) La Plata, Argentina and \$Departamento de Ciencias \\ Biológicas, Facultad de Ciencias Exactas y Naturales, Universidad de Buenos Aires, Ciudad Universitaria, (1428) \\ Buenos Aires, Argentina
}

\begin{abstract}
The 15 species in the weevil genus Galapaganus Lanteri 1992 (Entiminae: Curculionidae: Coleoptera) are distributed on coastal Perú and Ecuador and include 10 flightless species endemic to the Galápagos islands. These beetles thus provide a promising system through which to investigate the patterns and processes of evolution on Darwin's archipelago. Sequences of the mtDNA locus encoding cytochrome oxidase subunit I (COI) were obtained from samples of seven species occurring in different ecological zones of the oldest south-eastern islands: San Cristóbal, Española and Floreana, and the central island Santa Cruz. The single most parsimonious tree obtained shows two well-supported clades that correspond to the species groups previously defined by morphological characters. Based on a mtDNA clock calibrated for arthropods, the initial speciation separating the oldest species, G. galapagoensis (Linell) on the oldest island, San Cristóbal, from the remaining species in the Galápagos occurred about 7.2 Ma. This estimate exceeds geological ages of the extant emerged islands, although it agrees well with molecular dating of endemic Galápagos iguanas, geckos and lizards. An apparent explanation for the disagreement between geological and molecular time-frames is that about $7 \mathrm{Ma}$ there were emerged islands which subsequently disappeared under ocean waters. This hypothesis has gained support from the recent findings of 11-Myr-old submarine seamounts (sunken islands), south-east of the present location of the archipelago. Some species within the darwini group may have differentiated on the extant islands, 1-5 Ma.
\end{abstract}

Keywords: cytochrome oxidase I, DNA sequences, island biogeography, progression rule, speciation, taxon cycle.

\section{Introduction}

Island archipelagos enable the study as well as the process of speciation (Darwin, 1859; Carlquist, 1974; Grant, 1986). Because island systems comprise sets of often relatively small areas (i.e. patches) separated by uninhabitable gaps, they provide multiple opportunities for isolation of small populations. They also offer the potential for comparative studies of the interactions of habitat patchiness, species vagility, and time in the process of species formation. This potential has begun to be exploited (Grant, 1994; Juan et al., 1995; Wagner \& Funk, 1995; Roderick \& Gillespie, 1998). The three oceanic island archipelagos that have been subject to repeated studies of species' radiations are the Canary Islands (Thorpe et al., 1994; Juan et al., 1995, 1996) the

*Correspondence. E-mail: bfarrell@oeb.harvard.edu
Galápagos Islands (Darwin, 1859; Grant, 1986; Carson, 1992; Lanteri, 1992; Cook et al., 1995; Peck, 1996) and the Hawaiian Islands (DeSalle \& Hunt, 1987; Gillespie et al., 1994; Carson \& Clague, 1995; DeSalle, 1995; Wagner \& Funk, 1995; Roderick \& Gillespie, 1998).

The origin of the flora and fauna endemic to the Galápagos Islands has been of interest since the publication of The Voyage of the Beagle (Darwin, 1845). Evidence of general affinities with coastal South America has accumulated since Darwin's first collections (Snodgrass, 1902; Wright, 1983; Grant, 1986; Lanteri, 1992; Lopez et al., 1992; Peck, 1994, 1996; Cook et al., 1995; Rassmann, 1997), and there has been recent progress on elucidating the relationships among the forms endemic to the various islands (Lopez et al., 1992; Cook et al., 1995; Finston \& Peck, 1997).

Phylogenetic patterns, for example, might indicate whether the species endemic to various subsets of islands 
arose most frequently through repeated dispersal from the mainland or from neighbouring islands (Gillespie et al., 1994). Phylogenetic patterns common to different groups might even favour a few particular histories of colonization and dispersal among islands (Gillespie et al., 1994; DeSalle, 1995; Wagner \& Funk, 1995; Roderick \& Gillespie, 1998).

Although the sequence of events implied by the branching order of phylogeny estimates can lend support to particular sequences of island colonization (Funk \& Wagner, 1995), estimates of molecular divergence are useful in establishing their respective timing. This seems especially important in both the Canaries (Juan et al., 1996) and the Galápagos (Christie et al., 1992) because the oldest islands (Fuerteventura and San Cristóbal, respectively) in these chains are also the most proximal $(110 \mathrm{~km}$ and $1000 \mathrm{~km}$, respectively) to dominant oceanic currents from the direction of the mainland (the Hawaiian Islands are much more isolated at $4000 \mathrm{~km}$ from the nearest continent).

Moreover, because the respective ages of islands in such volcanic archipelagos are also generally reflected in their spatial distributions, occasional dispersal (e.g. interisland rafting) followed by speciation - all entirely post-island formation - could produce a phylogenetic pattern comparable to that expected if speciation followed in tandem with island formation (Roderick \& Gillespie, 1998).

As is also true of the Hawaiian Islands and the Canaries, the presently emerged Galápagos Islands are the most recent products of a long-lived mantle hotspot (Christie et al., 1992; White et al., 1993). Age estimations of the extant islands are indeed variable: $\mathrm{K}-\mathrm{Ar}$ radiometry and marine fossils on the extant islands indicate a maximum age of the oldest exposed land on the order of 3-4 Myr (Geist et al., 1985; Hickman \& Lipps, 1985), whereas different geological plate motion models set a maximum age of emergence in the range of 4.5-6.3 Myr, depending on the velocity of the Nazca plate $\left(55 \mathrm{~mm} \mathrm{yr}^{-1}, 37 \mathrm{~mm} \mathrm{yr}^{-1}\right.$, respectively) (White et al., 1993; Geist, 1996). Although the emerged islands are evidently young, drowned seamounts east of the existing San Cristóbal island in the Galápagos archipelago are from 5 to $11 \mathrm{Myr}$ old and the history of island production over this hotspot probably extends back 15-20 Myr, and maybe even 80-90 Myr (Christie et al., 1992).

Early reports of surprisingly great divergence in proteins have thus recently been reconciled with the dynamic history of this island chain. Investigations of enzyme-electrophoresis and immunological data of the Galápagos iguanid genera Amblyrhynchus Bell and Conolophus Fitzinger suggest a divergence time of 15-20 Myr relative to other iguanines (Wyles \& Sarich, 1983), a range recently confirmed by DNA sequence-based estimates (Rassmann, 1997). Also favouring a range of ages older than the extant islands is the molecular clock calibrations for the gecko and lizard genera Phyllodactylus Gray and Tropidurus Wied which yield ages of 8.9 Myr and 10.2 Myr, respectively (Wright, 1983; Lopez et al., 1992).

Although the ancestors of these lizards are likely to have originally colonized a now-submerged island, other elements of the fauna may be more recent in origin. Enzyme electrophoretic analyses of the 13 Darwin finch species (Emberizinae) suggest divergences within $5 \mathrm{Myr}$ or less (Grant, 1994), within the age-range of the present islands (White et al., 1993). This is consistent with some recent studies of insects (Finston \& Peck, 1997), which show little allozyme differentiation among marked morphological groups endemic to the various islands.

It is not surprising that the Galápagos fauna reflects a continuous history of colonization, both preceding and postdating the emergence of the present islands. Comparative studies of the effects of vagility or body size on speciation might profit by study of groups of similar age on the islands (Carson \& Clague, 1995), whereas focus on the rate of speciation might compare groups of similar vagility or size. In general, larger bodied and/or more vagile animals are probably less likely to be affected by the spatial and temporal history of island archipelagos, per se, because they may more readily disperse among islands. However, larger species may also be more likely to suffer higher extinction rates.

The phylogenesis of small, sedentary organisms such as flightless insects or other arthropods (or small vertebrates such as anoles) may more often reflect both their history of colonization and the patchiness of island systems in space and time. These have been the focus of numerous studies, yielding some insights into the assembly of island faunas.

One such group, the curculionid weevil genus Galapaganus Lanteri (1992) (subfamily Entiminae, tribe Naupactini), provides a promising system for investigation of patterns and processes of assembly of faunas in the Galápagos Islands, especially for speciation within the archipelago. The 15 species of these weevils include 10 species endemic to the Galápagos Islands that are flightless, fairly heavy-bodied, and probably less vagile than many arthropod groups. The larvae eat roots and the adults eat foliage. Although their habits are known imprecisely, most of them appear to be polyphagous.

Here we provide a phylogenetic analysis of DNA sequences from the mitochondrial locus encoding subunit I of the enzyme cytochrome oxidase (COI). These data are analysed together with morphological characters from an earlier study (Lanteri, 1992) to evaluate whether the phylogenesis of these weevils parallels the 
apparent history of island formation; and whether the amount of sequence divergence favours colonization and speciation after, during or before the formation of the emergent islands.

\section{Materials and methods}

\section{Sampling}

The specimens studied herein were collected by A. Lanteri, S. Peck (Canada) and L. R. Albelo (Ecuador), in the Galápagos islands between March and May 1996. Samples were obtained from Santa Cruz, San Cristóbal, Floreana and Española (Fig. 1). These islands are considered the oldest in the archipelago and show several vegetation and ecological zones from the arid coasts to the moist highlands (Wiggins \& Porter, 1971; Peck, 1996) (Table 1). Specimens were captured on shrubs using a beating sheet, with a sweeping net, or by hand from trailing plants (G. collaris Lanteri).

We were able to sample the six species occurring on Santa Cruz, San Cristóbal, Floreana and Española islands and a seventh species $G$. howdenae Lanteri, widespread in mainland Ecuador and recently introduced in an agricultural area of Santa Cruz in Galápagos [according to Peck et al. (1998), of the over 300 insect species recently introduced to the Galápagos, 60 are plant-feeding beetles]. Of the seven species studied, one belongs to the femoratus species group ( $G$. howdenae Lanteri), and six species (G. ashlocki Lanteri, G. caroli (Van Dyke), G. collaris Lanteri, G. conwayensis (Mutchler), G. galapagoensis (Linell) and G. vandykei
Lanteri were assigned to the darwini species group (Lanteri, 1992). Most of the species analysed (five out of seven) are single-island endemics. However, the material available for molecular studies does not include cospecifics from different islands for $G$. collaris and G. vandykei; this precludes assessment of intraspecific variation and analysis of inter-island divergence and island colonization below the species level. Outgroups included three species in the naupactine genus Naupactus Dejean. Details of all material studied are included in Table 2, and the overall known distributions and ecological zones of species of Galapaganus herein studied are given in Table 3.

\section{DNA preparation, PCR amplification and sequencing}

Collected specimens were preserved refrigerated in $100 \%$ ethanol. A single specimen of each species was selected for the analysis. Ethanol-preserved individuals were left to dry for a few minutes before grinding. Whole weevil specimens were ground to fine powder, in a mortar with liquid nitrogen. DNA was isolated according to the protocol of Normark (1996) for ethanol-preserved individuals.

One microlitre (200 ng) of the DNA solution obtained was amplified to produce a double-stranded product under the following conditions: $2 \mu \mathrm{M}$ of each primer, $200 \mu \mathrm{M}$ each dNTP, $2 \mu \mathrm{M} \mathrm{MgCl}_{2}$, buffer supplied by the manufacturer (Promega) and 1.25 units Taq polymerase (Promega), in a total volume of $50 \mu \mathrm{L}$. A typical temperature profile consisted of 40

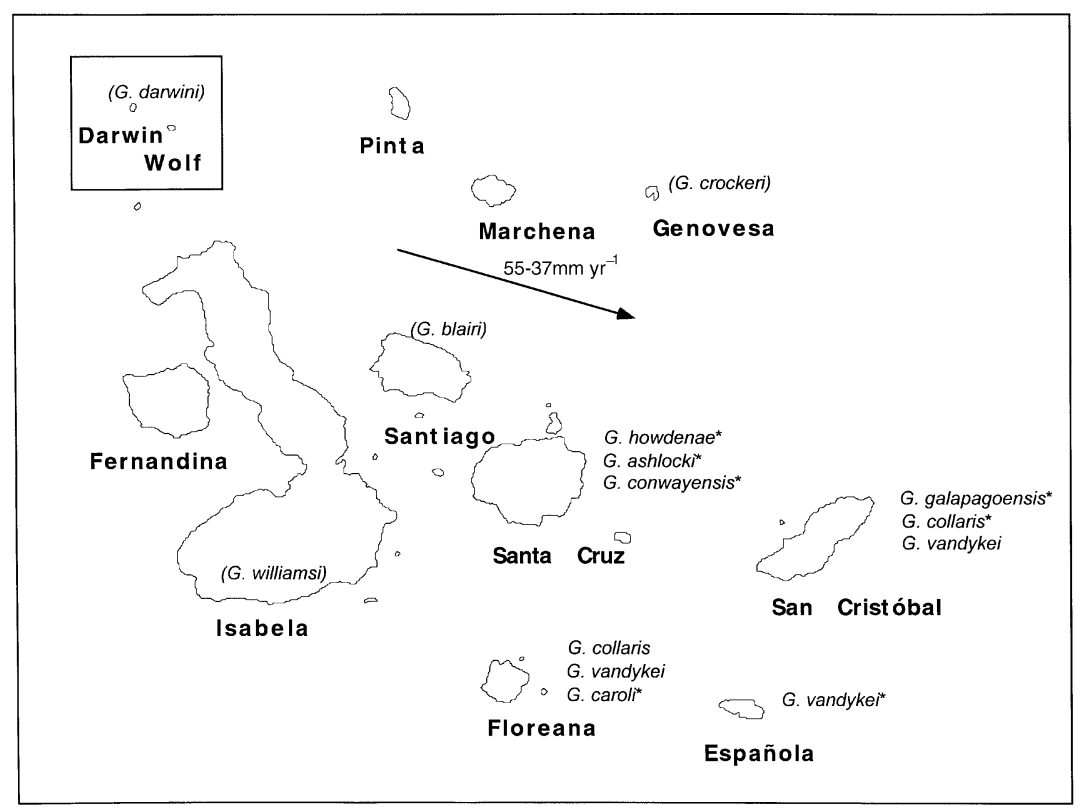

Fig. 1 Distribution of species of Galapaganus occurring on the Galápagos archipelago. Species in brackets are not analysed. Asterisks indicate the origin of the specimens analysed in this study. Arrow shows the direction and speed of motion of the Nazca Plate. 
Table 1 Galápagos Islands: ecological diversity (sum of an island's vegetational zones) and estimates for geological ages in millions of years since the emergence of the islands

\begin{tabular}{lccc}
\hline & & \multicolumn{2}{c}{ Age (Myr) } \\
\cline { 3 - 4 } Island & $\begin{array}{c}\text { Ecological diversity } \\
\text { (no. of ecological zones) }\end{array}$ & $\begin{array}{c}\text { Minimum } \\
(\mathrm{K}-\mathrm{Ar})^{\mathrm{b}}\end{array}$ & $\begin{array}{c}\text { Maximum } \\
\text { (hotspot) }^{\mathrm{c}, \mathrm{d}}\end{array}$ \\
\hline San Cristóbal & 6 & 2.3 & $4.5-6.3$ \\
Española & 2 & 2.8 & $4.1-5.6$ \\
Floreana & 4 & 1.5 & 3.3 \\
Santa Cruz & 6 & 2.2 & $2.7-3.6$ \\
\hline
\end{tabular}

$\mathrm{K}-\mathrm{Ar}$, Potassium-argon datings (minimum) and hotspot model datings (maximum). Data taken from Peck (1996) ${ }^{\mathrm{a}}$, White et al. $(1993)^{\mathrm{b}}$, Cox $(1983)^{\mathrm{c}}$ and Geist $(1996)^{\mathrm{d}}$.

Table 2 Details of the material studied

\begin{tabular}{|c|c|c|c|}
\hline Species & Locality/altitude/date & Notes & Collector \\
\hline $\begin{array}{l}\text { Galapaganus } \\
\text { galapagoensis } \\
\text { (Linell 1898) }\end{array}$ & $\begin{array}{l}\text { Ecuador, Galápagos, San Cristóbal Is., } \\
5 \text { km SE Wreck Bay, } 0 \text { m, 13/3/96 }\end{array}$ & $\begin{array}{l}\text { On Cryptocarpus pyriformis, } \\
\text { Laguncularia racemosa and } \\
\text { Gossypium barbadense, at night }\end{array}$ & Lanteri \\
\hline $\begin{array}{l}\text { Galapaganus collaris } \\
\text { Lanteri } 1992\end{array}$ & $\begin{array}{l}\text { Ecuador, Galápagos, San Cristóbal Is., } \\
\text { El Junco rim, } 620 \text { m, 14/3/96 }\end{array}$ & $\begin{array}{l}\text { On Verbena litoralis, } \\
\text { in the evening }\end{array}$ & Lanteri \\
\hline $\begin{array}{l}\text { Galapaganus caroli } \\
\text { (Van Dyke 1953) }\end{array}$ & $\begin{array}{l}\text { Ecuador, Galápagos, Floreana, Bahia } \\
\text { Las Cuevas, 5-m, arid zone, 16/4/96 }\end{array}$ & Hand collection & Peck \\
\hline $\begin{array}{l}\text { Galapaganus vandykei } \\
\text { Lanteri } 1992\end{array}$ & $\begin{array}{l}\text { Ecuador, Galápagos, Española Is., } \\
\text { Punta Suarez, arid zone, 23/3/96 }\end{array}$ & At night, hand collection & Peck \\
\hline $\begin{array}{l}\text { Galapaganus ashlocki } \\
\text { Lanteri } 1992\end{array}$ & $\begin{array}{l}\text { Ecuador, Galápagos, Santa Cruz Is., } \\
\text { trail to Cerro Crocker, } 400-800 \text { m, } \\
\text { Miconia zone, } 9 / 2 / 96\end{array}$ & At noon & Lanteri \\
\hline $\begin{array}{l}\text { Galapaganus conwayensis } \\
\text { (Mutchler 1938) }\end{array}$ & $\begin{array}{l}\text { Ecuador, Galápagos, Santa Cruz Is., } \\
\text { Tortuga Bay trail, } 0-5 \mathrm{~m}, 10 / 3 / 96\end{array}$ & $\begin{array}{l}\text { On Cryptocarpus pyriformis, } \\
\text { Cordia lutea and } \\
\text { Alternanthera echinocephala }\end{array}$ & Lanteri \\
\hline $\begin{array}{l}\text { Galapaganus howdenae } \\
\text { Lanteri } 1992\end{array}$ & $\begin{array}{l}\text { Ecuador, Galápagos, Santa Cruz Is., } \\
4 \text { km from Bella Vista, 19/3/96 }\end{array}$ & $\begin{array}{l}\text { On Erythrina and other plants of } \\
\text { the agricultural area, at noon }\end{array}$ & Lanteri \\
\hline $\begin{array}{l}\text { Naupactus verecundus } \\
\text { Hustache } 1947\end{array}$ & $\begin{array}{l}\text { Argentina, La Pampa, Santa Rosa, } \\
6 / 12 / 95\end{array}$ & On grasses & de Wysiecki \\
\hline $\begin{array}{l}\text { Naupactus xanthographus } \\
\text { (Germar 1824) }\end{array}$ & $\begin{array}{l}\text { Argentina, Buenos Aires, Punta Lara, } \\
7 / 2 / 97\end{array}$ & On Malvaceae & $\begin{array}{l}\text { Lanteri \& } \\
\text { Loiacono }\end{array}$ \\
\hline $\begin{array}{l}\text { Naupactus dissimulator } \\
\text { Boheman } 1840\end{array}$ & $\begin{array}{l}\text { Argentina, Buenos Aires, Punta Lara, } \\
7 / 2 / 97\end{array}$ & On shrubs & $\begin{array}{l}\text { Lanteri \& } \\
\text { Loiacono }\end{array}$ \\
\hline
\end{tabular}

cycles: $94^{\circ} \mathrm{C}$ for $30 \mathrm{~s}, 50^{\circ} \mathrm{C}$ for $30 \mathrm{~s}$ and $72^{\circ} \mathrm{C}$ for $1 \mathrm{~min}$ $15 \mathrm{~s}$, followed by a 5 -min extension step at $72^{\circ} \mathrm{C}$. The product of this reaction was purified after being run on an agarose gel (QIAquick columns, Qiagen Valencia, CA, USA) or directly purified on Centricon 30 columns (Amicon, Beverly, MA, USA). The amount of DNA was estimated using a spectrophotometer and $90 \mathrm{ng}$ was sequenced using $\mathrm{ABI}$ dye terminator sequencing kits (PE biosystems, Warrington, UK), following the provided instructions but using half reactions.

The entire cytochrome oxidase I (COI) gene of mtDNA was amplified using the polymerase chain reac- tion (PCR). COI specific primer pairs S1718, A2411 and S2215, A2940 were usually used, although S1859 was used sometimes. They were obtained from the Harrison Laboratory (Cornell University) and Farrell Laboratory (Harvard University) and used to amplify and to sequence COI of the weevils studied. The sequencing primers were the external primers for each fragment with extra internal primers S2336, S2442, A2191 and A2831 (for primer sequences see Normark, 1996; Normark et al., 1999). Sequencing of this doublestranded product was carried out using 25 PCR cycles of $96^{\circ} \mathrm{C}$ for $30 \mathrm{~s}, 50^{\circ} \mathrm{C}$ for $15 \mathrm{~s}$ and $60^{\circ} \mathrm{C}$ for $4 \mathrm{~min}$ with a $2^{\circ} \mathrm{C}$ increase per $\mathrm{s}$ in a $10-\mathrm{L}$ reaction. A 1226 -bp region

(C) The Genetical Society of Great Britain, Heredity, 85, 20-29. 
Table 3 Distribution of the studied species of Galapaganus

\begin{tabular}{lll}
\hline Species & \multicolumn{1}{c}{ Distribution } & Ecological zones \\
\hline Galapaganus galapagoensis & San Cristóbal & Littoral to arid zone \\
Galapaganus collaris & San Cristóbal, Floreana & Fern-sedge zone \\
Galapaganus caroli & Floreana & Littoral to transition zone \\
Galapaganus ashlocki & Santa Cruz & Miconia and fern-sedge zones \\
Galapaganus vandykei & Floreana, Española, San Cristóbal & Littoral zone \\
Galapaganus conwayensis & Santa Cruz & Littoral to Scalesia zones \\
Galapaganus howdenae & Mainland Ecuador & Native forest \\
& Santa Cruz & Agricultural area \\
\hline
\end{tabular}

Ecological zones according to Wiggins \& Porter (1971) are progressively more mesic away from the coast: (1) littoral zone (salt tolerant vegetation); (2) arid zone (microphyllous, xerophytic vegetation); (3) transition zone (dry woodland); (4) Scalesia zone (mesophyllous, mainly evergreen forest); (5) Miconia zone (mesophyllous evergreen shrub) and (6) pampa or fern-sedge zone (with ferns as the most obvious part of the vegetation). Coastal lowlands are seasonally arid and highlands (Miconia and pampa zones, over $500 \mathrm{~m}$ ) are more stable and humid.

of the mtDNA cytochrome oxidase I (COI) gene was sequenced for eight of the weevil species studied, whereas 691 bases were analysed for G. caroli and $N$. dissimulator Boheman. The complete sequence for $N$. xanthographus (Germar) was obtained by compiling two 700-base fragments from two different individuals (one sequence kindly provided by B. Normark). Each sequence was entered and compiled using SEQUENCHER 3.0 (Genecodes Corporation, Ann Arbor, MI). The complete set of sequences has been submitted to Genbank under accession numbers: AF015914 and AF211483-AF211491.

\section{Phylogenetic analysis}

A matrix was assembled of 1226 molecular and 33 morphological characters (characters and character states are described in Lanteri, 1992) which were treated as unordered. The molecular dataset was analysed separately and in a combined total evidence matrix together with the morphological characters. Changes at the third codon position were downweighted, giving all other changes a weight of up to 5 , and the analysis was also performed using only first and second codon positions. Most parsimonious phylogenetic trees were inferred using the exhaustive search function in PAUP 4.0 (Swofford, 1998). Branch and bound bootstrap searches were performed with random addition sequences of taxa with 10 repetitions for each of 100 replications (Fig. 2). Trees were rooted with the Neotropical naupactine genus Naupactus Dejean as outgroup, using sequences of species $N$. verecundus Hustache, $N$. xanthographus and $N$. dissimulator. Based on morphological evidence this genus is one of the closest relatives of Galapaganus (Lanteri, 1992). Substitution rates were calculated using the Kimura 2-parameter model (Kimura, 1980) and the pairwise sequence divergence matrix was built using PAUP's distance matrix function (Table 4).
Relative rate tests were performed to test the equality of evolutionary rates between lineages (Li \& Bousquet, 1992) using PHYLTEST 2.0 (Kumar, 1996). Likelihood ratio tests (LTR) were performed using the likelihood scores calculated for the most parsimonious tree with and without the constraint of a molecular clock as implemented in PAUP. The statistic $(-2 \log \Delta, \Delta=\max \mathrm{L}$ null hypothesis/max $\mathrm{L}$ alternative hypothesis) can be compared to a $\chi^{2}$ distribution with $n-2$ degrees of freedom ( $n$, number of taxa) to determine the significance of the test (Felsenstein, 1981; Huelsenbeck \& Rannala, 1997).

The divergence times between lineages were calculated from uncorrected pairwise values and calibrated using $2.3 \%$ pairwise divergence per million years based on the arthropod mtDNA survey of Brower (1994). This may bias our estimates towards younger ages, because COI is more conservative (e.g. $72 \%$ identity between Apis and Drosophila - higher than any other gene) than other protein and RNA genes in the insect mitochondrial genome (Crozier \& Crozier, 1993).

\section{Results}

\section{Phylogeny}

A single most parsimonious tree was obtained when analysing the molecular data alone, and in combination with the morphological characters (761 steps long, $\mathrm{CI}=0.73, \mathrm{RI}=0.39$; Fig. 2). Out of 1226 molecular characters, 570 are constant, 456 are parsimony uninformative and 200 are informative. Most substitutions are at third codon positions, and are silent. However, the same topology was obtained giving changes at the third codon position a weight of 1 and all other changes a weight of up to 5 and also when including only first and second codon positions. The 
Fig. 2 Most parsimonious tree for the species of Galapaganus obtained from the analysis of a combined morphological and molecular matrix. Numbers on the branches indicate bootstrap values for the unweighted combined dataset and branch lengths are proportional to the amount of molecular change without correction for multiple substitutions. Following each species name is a rectangle containing a map of the four islands where the island(s) occupied are shaded. Similarly the schematic circles indicate which of the six roughly concentric ecological zones are occupied on each island by each weevil species.

Table 4 Pairwise sequence divergence values (Kimura 2-parameter model values) within the genus Galapaganus

$\begin{array}{llllll}\text { G. } h & \text { G. } g & \text { G. car } & \text { G.v } & \text { G. a } & \text { G. coll }\end{array}$

G. howdenae

G. galapagoensis 0.245

$\begin{array}{lll}G \text {. caroli } & 0.281 & 0.156\end{array}$

$\begin{array}{llll}\text { G. vandykei } & 0.251 & 0.149 & 0.091\end{array}$

$\begin{array}{llllll}\text { G. ashlocki } & 0.265 & 0.147 & 0.098 & 0.090\end{array}$

$\begin{array}{lllllll}\text { G. collaris } & 0.273 & 0.215 & 0.137 & 0.122 & 0.126\end{array}$

$\begin{array}{llllllll}G . & \text { conwayensis } & 0.261 & 0.173 & 0.124 & 0.121 & 0.107 & 0.124\end{array}$

transition/transversion ratio is $1.1: 1$; the GC content is $32 \%$, and the maximum divergence between Galapaganus species groups is $28 \%$ (between G. howdenae and G. caroli) whereas within the darwini group it ranges from 17\% (between G. galapagoensis and G. collaris) to $9 \%$ (between $G$. caroli and G. vandykei) (Table 4).

High bootstrap values $(>80)$ (Fig. 2) support the monophyly of Galapaganus and the darwini group and agree in this sense with the cladogram based on morphological characters (Lanteri, 1992). The topology shows $G$. howdenae (i.e. the femoratus group) at a basal position, as sister group to the darwini group. Within the darwini group G. galapagoensis is basal and there are two subgroups, one including G. caroli-G. vandykei, and other comprising G. ashlocki-G. conwayensis-
G. collaris. The position of $G$. ashlocki is not well supported by bootstrap values.

This combined analysis tree differs in several respects from that based solely on morphology. The relationships among these Galapaganus species based on 33 morphological characters as in Lanteri (1992) are ( $G$. howdenae (G. conwayensis (G. ashlocki, G. caroli (G. vandykei (G. galapagoensis, G. collaris))))). The combined analyses place $G$. galapagoensis as the basal species of the darwini group and sister group to G. ashlocki (G. collaris-G. conwayensis). On the other hand, the morphological MPT places $G$. conwayensis close to the root, with $G$. galapagoensis-G. collaris forming a monophyletic group together with $G$. vandykei.

The nucleotide substitution rates among the members of the Galapaganus genus were compared with respect to the outgroup Naupactus $(z=1.89)$. The relative rates were also analysed within the darwini group clade using $G$. howdenae as outgroup because the choice of a closely related outgroup is critical for analysing relative rates in a given clade $(z=1.54)$. According to the relative rate test, Galapaganus lineages are not evolving at significantly different speeds because no rate heterogeneity was found among the substitution rates at the 0.05 probability level. Furthermore, according to the LRT, the molecular clock hypothesis (where the rates among lineages are equal) cannot be rejected for this dataset $(P>0.05)$. 


\section{Age of divergence of Galapaganus lineages}

Based on the mtDNA clock proposed by Brower (1994) for arthropods, the age for the diversification of the two species groups within Galapaganus is $11 \mathrm{Myr}(10.7-12.1)$ (late Miocene). The minimum time for speciation of the darwini group within the archipelago is about $7.2 \mathrm{Myr}$ (6.8-7.4) (early Pliocene). Even considering that stochastic errors can be associated with the calculations of age of divergences, this value of 7.2 Myr exceeds the oldest estimates for the islands, especially as Geist (1996) states that the last reported age for San Cristobal $(6.3 \mathrm{Myr})$ is based on very few concrete data and should be viewed only as an estimate. All previous estimates agree that the maximum age for the extant archipelago is 4.5 Myr (Cox, 1983; Geist et al., 1985; Hickman \& Lipps, 1985; White et al., 1993). Within the darwini group the divergence between the clade including the sister species G. vandykei-G. caroli (Española-FloreanaSan Cristóbal), and the clade including G. collarisG. conwayensis-G.ashlocki (Santa Cruz-San Cristóbal) is estimated at $5 \mathrm{Myr}$ (mid-Pliocene). Galapaganus vandykei and G. caroli would have started their divergence about $3.5 \mathrm{Ma}$ (late Pliocene).The position of G. ashlocki in the consensus tree is not resolved and, accordingly, its divergence from related species is not distinguishable from the age estimated for the basal node of the clade (5 Myr). The estimates within the darwini group do not exceed the maximum ages of the islands provided by geological analyses, although they are above the minimum estimates (Table 1).

\section{Discussion}

Our estimate of Galapaganus phylogeny places the oldest weevil species on the oldest island, G. galapagoensis on San Cristóbal, as basal to the rest of the darwini group. This is also the pattern in the flightless scarab genus Neoryctes Arrow (Cook et al., 1995) and in the lizard genera Tropidurus and Phyllodactylus (Wright, 1983). Neoryctes has not yet been subject to molecular study. However, Tropidurus, Phyllodactylus (Lopez et al., 1992) and Galapaganus all show molecular divergence in apparent excess of the age of even this oldest island. This suggests that the initial colonizations by these groups occurred on a now submerged seamount east of San Cristóbal before the remaining, younger islands had appeared.

The iguanids and these weevils are thus among the older members of the Galápagos' fauna. Because the common ancestor of the darwini group is most parsimoniously ascribed flightlessness, this was either the condition of the original colonizing species or evolved between colonization and the first subsequent speciation event. The external morphology of the darwini group is typical of weevils from deserts or highlands and includes a very sclerotized integument, scales modified into dense setae as well as absent hind-wings (Lanteri, 1992). These apparent adaptations to aridity were probably essential for colonization and establishment on littoral zones on the islands where the only available vegetation is salttolerant shrubs (Finston \& Peck, 1997). In contrast, the morphology of the fully winged and flight-capable femoratus group suggests adaptation to more mesic environments than that of the darwini group. Both $G$. howdenae and G. femoratus (as well as two additional species, as yet undescribed) have an integument that is only moderately sclerotized and is covered with iridescent scales.

The source of the founder(s) of the Galapaganus darwini group is apparently coastal Ecuador/Perú, probably rafted via the Humboldt current (Wright, 1983; Peck \& Kukalova-Peck, 1990; Lopez et al., 1992). This current arises off Antarctica, flows northward along the coast of Chile and Perú and joins the South Equatorial current that passes through the Galápagos archipelago carrying along great quantities of flood debris and pleuston, facilitating the passive transport of terrestrial animals (Peck, 1994).

\section{Distribution and speciation of the darwini group on the Galápagos islands}

The six darwini group species sampled here are representative of the ecological diversification that has apparently accompanied Galapaganus phylogenesis in these islands. The phylogeny estimate is consistent with the taxon cycle model of island faunal development (Wilson, 1961) in that the basal species occur in arid, coastal areas whereas the more derived species occur in the upland and more mesic habitats (Fig. 2). This is also consistent with the colonization by rafting of a flightless ancestor, as a winged arrival of a form more closely resembling the mesic-adapted femoratus group might be at least as likely to have been in the uplands.

The shifts from coast to upland are coincident with speciation of the darwini group, which probably occurred in the following manner: initial colonization of a now submerged island east of San Cristóbal from coastal Perú, with subsequent dispersal and speciation in Española, Floreana and Santa Cruz, and a recolonization of San Cristóbal and Floreana from the latter island. The molecular divergence (Table 4) within the darwini group, at the upper end of the range expected given the ages of the islands (Table 1), suggests that some speciation events may have occurred in tandem with island emergence. Therefore, the speciation within this clade could have occurred on the presently emerged 
islands. Thus if we accept the implication based on the cladogram topology and molecular divergence that the occurrence of the basal species on the oldest island reflects history, then a logical inference would be that the species' distributions on the other, younger islands also partly reflect the history of emergence.

Although Hickman \& Lipps (1985) determined the 3-4 Myr age of these islands accurately from fossil evidence, their conclusion that this age sets the upper limit for island evolution is thus not entirely correct. Some speciation of Galápagos endemic Galapaganus weevils, Tropidurus and Conolophus lizards apparently took place before the emergence of the oldest extant islands, and these are probably not unusually old elements of the Galápagos fauna.

Recent molecular phylogenetic studies of flightless beetles in the Canary Islands show similar patterns. Like Galapaganus, the flightless tenebrionid genera Hegeter and Pimelia each reflect the historic sequence of island formation, with the cladistically basal lineages restricted to the oldest island Fuerteventura (Juan et al., 1995, 1996). Although flightless beetles may be faithful markers of island biogeographical history, other groups of organisms also lend support to the historical model of island faunal development.

Recent overviews of Hawaiian island biogeography indicate a strong influence of volcanic history on both the flora and fauna (Wagner \& Funk, 1995; Roderick \& Gillespie, 1998). Like the Galápagos, this hotspot chain is tens of millions of years old, but the presently emergent islands are only 1-5 Myr (Carson \& Clague, 1995). Molecular phylogenetic studies of Drosophila (DeSalle \& Hunt, 1987), spiny-leg Tetragnatha spiders (Gillespie et al., 1994), and the Malvaceae plant genera Remya Hillebr., Hesperomannia Gray and Kokia Lewton show clear correspondence to the sequence of appearance of these islands, whereas Geranium L. and silverswords (Argyroxiphium D. C. and Wilkesia Gray) exhibit more complex biogeographical patterns (Funk \& Wagner, 1995).

Analyses of mtDNA sequences for the Hawaiian Drosophilidae (DeSalle, 1995) corroborate the early inference of colonization in the Miocene or earlier, an age exceeding that of the presently emerged islands (Carson \& Kaneshiro, 1976). However, the more vagile Hawaiian honeycreepers, like the Galápagos finches, represent a very recent radiation with little correspondence to island history (Funk \& Wagner, 1995).

It is becoming clear that at least some elements of the biota of the Galápagos reflect the long-term history of this hotspot archipelago, as is certainly the case for the Hawaiian Islands and perhaps for the Canaries as well. As with the evolution of floras, where the oldest plant groups are often host to the oldest herbivores (Farrell,
1998), the long-term persistence of historical patterns implies some constraints on dispersal or host shift. Island systems also parallel floras in permitting replicated study of the macroevolutionary consequences of colonization (Strong et al., 1984; Farrell \& Mitter, 1993).

Galapaganus weevils offer an initial molecular phylogenetic history of colonization of the Galápagos by arthropods. Further study of additional geographical representatives of the analysed species, as well as those of species of Galapaganus endemic to other islands (i.e. Isabela) and comparable lineages, will reveal whether the apparent history reported here is general. Comparative molecular systematic studies of other small, sedentary organisms, such as flightless arthropods, and of larger vertebrates, such as birds and lizards, may collectively resolve the history of this and other island archipelagos and help realize the unique advantage they provide for insights into the process of adaptive radiation.

\section{Acknowledgements}

Scientific research permits (Department of Forestry, Ministry of Agriculture, Republic of Ecuador) were issued through Dr Stewart Peck, head of the expedition to the Galápagos Islands. Field logistical support was obtained from the Charles Darwin Research Station (Santa Cruz Island), through directors D. Evans and C. Blanton. Fieldwork collaboration was provided for entomologists Stewart Peck (Canada) and Lazaro Roque Albelo (Ecuador). Fieldwork was partially supported by a research grant to S. Peck from the Natural Sciences and Engineering Research Council of Canada and National Geographic Society. Field and laboratory work were sponsored by research grants to A. Lanteri from Fundación Antorchas, Universidad Nacional de La Plata and CONICET (Argentina) and to V. Confalonieri from CONICET (Argentina). This research was also supported by a postdoctoral grant from Fundacion Antorchas to A. Sequeira, at Harvard University, and by a grant from the USDA to B. D. Farrell.

\section{References}

BROWER, A. V. Z. 1994. Rapid morphological radiation and convergence among races of the butterfly Heliconius erato inferred from patterns of mitochondrial DNA evolution. Proc. Natl. Acad. Sci. U.S.A., 91, 6491-6495.

CARLQuist, s. 1974. Island Biology. Columbia University Press, New York.

CARSON, H. L. 1992. The Galápagos that were. Nature, 355, 202-203.

CARSON, H. L. AND ClAGUe, D. A. 1995. Geology and biogeography of the Hawaiian Islands. In: Wagner, W. L. and 
Funk, V. A. (eds) Hawaiian Biogeography: Evolution on a Hot Spot Archipelago, pp. 14-29. Smithsonian Institution Press, Washington, DC.

CARSON, H. L. AND KANEShIRO, K. Y. 1976. Drosophila of Hawaii: systematics and ecological genetics. Ann. Rev. Ecol. Syst., 7, 311-345.

CHRISTIE, D. M., DUNCAN, R. A., McBIRNEY, A. R., RICHARDS, M. A., WHITE, W. M., HARPP, K. S. ET $A L$. 1992. Drowned islands downstream from the Galápagos hot spot imply extended speciation times. Nature, 355, 246-248.

COOK, J., HOWDEN, H. F. AND PECK, S. B. 1995. The Galápagos islands' genus Neoryctes Arrow (Coleoptera: Scarabaeidae: Dinastinae). Can. Entomol., 127, 177-193.

Cox, A. 1983. Ages of the Galápagos islands. In: Bowman, R. I., Berson, M. and Leviton, A. E. (eds) Patterns of Evolution in Galápagos Organisms, pp. 11-23. Pacific Division of the American Association for the Advancement of Science, San Francisco, CA.

CROZIER, R. H. AND CROZIER, Y. C. 1993. The mitochondrial genome of Apis mellifera: complete sequence and genome organization. Genetics, 133, 97-117.

DARWIN, c. 1845. The Voyage of the Beagle. John Murray, London.

DARwIN, C. 1859. On the Origin of Species. John Murray, London.

DESALLE, R. 1995. Molecular approaches to biogeographic analysis of Hawaiian Drosophilidae. In: Wagner, W. L. and Funk, V. A. (eds) Hawaiian Biogeography: Evolution on a Hot Spot Archipelago, pp. 72-89. Smithsonian Institution Press, Washington, DC.

DESAlle, R. AND HUNT, J. A. 1987. Molecular evolution in Hawaiian drosophiloids. Trends Ecol. Evol., 2, 212-216.

FARRELL, B. D. 1998. Inordinate fondness explained: Why are there so many beetles?. Science, 281, 555-559.

FARRELL, B. D. AND MITTER, C. 1993. Phylogenetic determinants of insect/plant community diversity. In: Ricklefs, R. E. and Schluter, D. (eds) Species Diversity: Historical and Geographical Perspectives, pp. 253-266. University of Chicago Press, Chicago, IL.

FELSENSTEIN, J. 1981. Evolutionary trees from DNA sequences: a maximum likelihood approach. J. Mol. Evol., 17, 368-376.

FINSTON, T. L. AND PECK, S. B. 1997. Genetic differentiation and speciation in Stomion (Coleoptera: Tenebrionidae): flightless beetles of the Galápagos Islands, Ecuador. Biol. J. Linn. Soc., 61, 183-200.

FUNK, V. A. AND WAGNER, W. L. 1995. Biogeographic patterns in the Hawaiian islands. In: Wagner, W. L. and Funk, V. A. (eds) Hawaiian Biogeography: Evolution on a Hot Spot Archipelago, pp. 379-419. Smithsonian Institution Press, Washington, DC.

GEIST, D. 1996. On the emergence and submergence of the Galápagos islands. Not. Galápagos, 56, 5-9.

GEIST, D., McBIRNEY, A. R. AND DUNCAN, R. A. 1985. Geology of Santa Fe Island: The oldest Galápagos volcano. J. Volcanol. Geotherm. Res., 26, 203-221.

GILlespie, R. G., CROOM, H. B. AND PALUMBI, S. R. 1994. Multiple origins of a spider radiation in Hawaii. Proc. Natl. Acad. Sci. U.S.A., 91, 2290-2294.
GRANT, P. R. 1986. Ecology and Evolution of Darwin's Finches. Princeton University Press, Princeton, NJ.

GRANT, P. R. 1994. Population variation and hybridization: comparison of finches from two archipelagos. Evol. Ecol., 8, 598-617.

HICKMAN, C. S. AND LIPPS, J. H. 1985. Geologic youth of Galápagos Islands confirmed by marine stratigraphy and paleontology. Science, 227, 1578-1580.

HUELSENBECK, J. P. AND RANNALA, B. 1997. Phylogenetic methods come of age: Testing hypotheses in an evolutionary context. Science, 276, 227-232.

JUAN, C., OROMI, P. AND HEWITT, G. M. 1995. Mitochondrial DNA phylogeny and sequential colonization of Canary Islands by darkling beetles of the genus Pimelia (Tenebrionidae). Proc. R. Soc. B, 261, 173-180.

JUAN, C., OROMI, P. AND HEWITT, G. M. 1996. Phylogeny of the genus Hegeter (Tenebrionidae, Coleoptera) and its colonization of the Canary Islands deduced from Cytrochrome Oxidase I mitochondrial DNA sequences. Heredity, 76, 392-403.

KIMURA, M. 1980. A simple method for estimating evolutionary rate of base substitution through comparative studies of nucleotide sequences. J. Mol. Evol., 16, 111-120.

KUMAR, S. 1996. PHYLTEST: A program for testing phylogenetic hypotheses, Version 2.0. Institute of Molecular Evolutionary Genetics and Department of Biology, The Pennsylvania State University, University Park, PA.

LANTERI, A. A. 1992. Systematics, cladistics and biogeography of a new weevil genus, Galapaganus (Coleoptera: Curculionidae) from the Galápagos islands, and coasts of Ecuador and Perú. Trans. Am. Entomol. Soc., 118, 227-267.

LI, P. AND BOUSQUET, J. 1992. Relative-Rate test for nucleotide substitutions between two lineages. Mol. Biol. Evol., 9, 1185-1189.

LOPEZ, T. J., HAUSELMAN, D. E., MAXSON, L. R. AND WRIGHT, J. W. 1992. Preliminary analysis of phylogenetic relationships among Galápagos Island lizards of the genus Tropidurus. Amphib-Reptilia, 13, 327-339.

NORMARK, B. B. 1996. Phylogeny and evolution of parthenogenetic weevils of the Aramigus tessellatus species complex (Coleoptera: Curculionidae: Naupactini): evidence from mitochondrial DNA sequences. Evolution, 50, 734-745.

NORMARK, B. B., JORDAL, B. H. AND FARRELL, B. D. 1999. Origin of a haplodiploid beetle lineage. Proc. R. Soc. B, 266, 1-7.

PECK, S. B. 1994. Sea surface (pleuston) transport of insects between islands in the Galápagos archipelago, Ecuador. Ann. Entomol. Soc. Am., 87, 576-582.

PECK, S. B. 1996. Diversity and distribution of the orthopteroid insects of the Galápagos Islands, Ecuador. Can. J. Zool., 74, $1497-1510$

PECK, S. B. AND KUKALOVA-PECK, J. 1990. Origin and biogeography of the beetles (Coleoptera) of the Galápagos Archipelago, Ecuador. Can. J. Zool., 68, 1616-1638.

PECK, S. B., HERATY, J., LANDRY, B. AND SINCLAIR, B. 1998. Introduced insect fauna on an oceanic archipelago: The Galápagos Islands, Ecuador. Am. Entomol., 44, 218-237. 
RASSMANN, C. 1997. Evolutionary age of the Galápagos iguanas predates the age of the present Galápagos islands. Mol. Phylogenet. Evol., 7, 158-172.

RODERICK, G. K. AND GILleSPIE, R. C. 1998. Speciation and phylogeography of Hawaiian terrestrial arthropods. Mol. Ecol., 7, 519-531.

SNODGRASS, R. E. 1902. Papers from the Hopkins Stanford Galápagos Expedition 1890-1899 VIII. Entomological results (7); Schistocerca, Sphingonotus, and Halmenus. Proc. Washington. Acad. Sci., 4, 411-454.

STRONG, D. R., LAwTON, J. H. AND SOUTHwoOd, T. R. E. 1984. Insects on Plants: Community Patterns and Mechanisms. Harvard University Press, Cambridge, MA.

SWOFFord, D. 1998. PAUP: Phylogenetic Analysis Using Parsimony, 4.0d64. Beta Version for Macintosh. Smithsonian Institution, Washington, DC.

THORPE, R. S., McGREGOR, D. P., CUMMING, A. M. AND JORDAN, W. C. 1994. DNA evolution and colonization sequence of island lizards in relation with geological history: mtDNA RFLP, cytochrome B, cytochrome oxidase, 12s rRNA and nuclear RAPD analysis. Evolution, 48, 230-240.

WAGNER, W. L. AND FUNK, v. A. 1995. Hawaiian Biogeography: Evolution on a Hot Spot Archipelago. Smithsonian Institution Press, Washington, DC.
WHITE, W. M., McBIRNEY, A. R. AND DUNCAN, R. A. 1993. Petrology and geochemistry of the Galápagos islands: portrait of a pathological mantle plume. J. Geophys. Res., 98, 19533-19563.

WIGGINS, I. L. AND PORTER, D. M. 1971. Flora of the Galápagos Islands. Stanford University Press, Stanford, CA.

WILSON, E. O. 1961. The nature of the taxon cycle in the Melanesian ant fauna. Am. Nat., 95, 169-193.

WRIGHT, J. W. 1983. The evolution and biogeography of the Lizards of the Galápagos Archipelago: evolutionary genetics of Phyllodactylus and Tropidurus populations. In: Bowman, R. I., Berson, M. and Leviton, A. E. (eds) Patterns of Evolution in Galápagos Organisms, pp. 123-155. Pacific Division of the American Association for the Advancement of Science, San Francisco, CA.

WYLES, J. S. AND SARICH, V. M. 1983. Are the Galápagos Iguanas older than the Galápagos? Molecular evolution and colonization models for the archipelago. In: Bowman, R. I., Berson, M. and Leviton, A. E. (eds) Patterns of Evolution in Galápagos Organisms, pp. 177-186. Pacific Division of the American Association for the Advancement of Science, San Francisco, CA. 